\title{
ANALISIS SURVIVAL PASIEN PENYAKIT GINJAL KRONIS DENGAN TERAPI PENGGANTI GINJAL DI RUMAH SAKIT PGI CIKINI PERIODE 2015-2020
}

\author{
Paskalia Clara Siahaan, Putu Ayu Swandewi Astuti* \\ Program Studi Sarjana Kesehatan Masyarakat, Fakultas Kedokteran, Universitas Udayana, \\ Jalan P.B. Sudirman, Denpasar, Bali, 80232
}

\begin{abstract}
ABSTRAK
Penyakit Ginjal Kronis (PGK) telah menjadi masalah kesehatan masyarakat yang mempengaruhi sebesar 10-16\% populasi orang dewasa di seluruh dunia. Tujuan penelitian ini untuk mengetahui survival pasien serta faktor-faktor yang berpengaruh terhadap survival pasien PGK yang menjalani terapi pengganti ginjal. Penelitian ini bersifat observasional analitik dengan rancangan studi hystorical cohort. Sebanyak 405 pasien digunakan sebagai kohort. Data dianalisis dengan metode Life Table, Kaplan Meier, Log Rank Test, dan uji Cox Regression. Hasil penelitian ini menunjukkan rata-rata survival pasien PGK dengan terapi pengganti ginjal adalah 50,7 bulan. Faktor yang berpengaruh bermakna terhadap survival pasien adalah kadar albumin $(\mathrm{HR}=0,499 ; 95 \% \mathrm{CI}=0,345-0,846 ; \mathrm{p}=0,001)$, umur pertama kali menjalani terapi pengganti ginjal ( $\mathrm{HR}=1,027 ; 95 \% \mathrm{CI}=0,997-1,041 ; \mathrm{p}=0,009)$, dan jenis asuransi kesehatan. Penanganan yang komperhensif terhadap kebutuhan nutrisi dan peradangan diperlukan untuk meningkatkan kadar albumin pasien. Pengambilan keputusan untuk pelaksanaan terapi pengganti ginjal pada pasien usia lanjut perlu dilakukan oleh dokter untuk meningkatkan survival pasien. Edukasi kesehatan serta pengoptimalan fungsi Posbindu PTM merupakan tindakan preventif terhadap penyakit PGK.
\end{abstract}

Kata Kunci: Analisis Survival, Penyakit Ginjal Kronis, Terapi Pengganti Ginjal

\section{ABSRACT}

Chronic Kidney Disease (CKD) has become a public health problem that affects $10-16 \%$ of the adult worldwide. The aim of this study was to see the survival and the factors that affect the survival of CKD patients undergoing kidney replacement therapy. The study was an analytic observational study with a hystorical cohort study design. A total of 405 patients were used as a cohort. Data were analyzed using the Life Table method, Kaplan Meier, Log Rank Test, and Cox Regression Test. The mean survival time of CKD patients with renal replacement therapy was 50,7 months. Factors that affected the patients' survival were albumin levels $(\mathrm{HR}=0,499 ; 95 \% \mathrm{CI}=0,345-0,846 ; \mathrm{p}=$ $0,001)$ and age at first undergoing renal replacement therapy $(\mathrm{HR}=1,027 ; 95 \% \mathrm{CI}=0,997-1,041) ; \mathrm{p}=0,009)$, and the type of health insurance. Comprehensive management of nutritional intake and inflammation is necessary to increase the albumin levels of dialysis patients. Consideration of decision-making for the implementation of renal replacement therapy in elderly patients with CKD need to be done by physicians to increase patient survival. Health education and optimizing the functions of Posbindu PTM can be done as a preventive measure against CKD.

Keywords: Survival Analysis, Chronic Kidney Disease, Renal Replacement Therapy

\section{PENDAHULUAN}

Penyakit tidak menular (PTM) merupakan permasalahan kesehatan yang telah menjadi isu strategis dalam agenda Sustainable Development Goals (SDGs) 2030 dan perlu menjadi prioritas pembangunan di setiap negara (Muhani dan Sari, 2020; Kemenkes RI, 2019). Penyakit Ginjal Kronik (PGK) merupakan salah satu dari PTM yang kasusnya terus meningkat di berbagai negara termasuk di Indonesia. PGK merupakan suatu keadaan klinis yang ditandai dengan penurunan fungsi ginjal yang bersifat progresif dan irreversible. Saat ini PGK telah menjadi salah satu masalah medis utama serta telah menjadi masalah kesehatan masyarakat yang mempengaruhi sebesar $10-16 \%$ populasi orang dewasa di seluruh dunia (Khan, dkk, 2018). Pada tahun 2017, terdapat 697.500.000 kasus PGK di seluruh dunia dengan prevalensi sebesar 9,1\% (Bikbov, dkk, 2020).

Di negara maju seperti Amerika Serikat, prevalensi PGK pada tahun 2016 sebesar $14,2 \%$ dengan 726.000 orang hidup 
dengan dialaisis kronis atau transplantasi ginjal (CDC, 2019). Berdasarkan hasil Riset Kesehatan Dasar (Riskesdas) tahun 2013 dan 2018 ditunjukkan bahwa prevalensi PGK di Indonesia pada usia $\geq 15$ tahun berdasarkan diagnosis dokter mengalami peningkatan, yaitu sebesar $0,2 \%$ pada tahun 2013 menjadi 0,38\% di tahun 2018 .

Penderita gagal ginjal pada suatu derajat tertentu memerlukan terapi pengganti ginjal yang berupa dialisis atau transplantasi ginjal untuk tetap bertahan hidup (CDC, 2017). Terdapat tiga modalitas terapi pengganti ginjal yang biasa digunakan, yaitu hemodialisis (HD), peritoneal dialysis (PD), dan trasplantasi ginjal (Pusdatin Kemenkes RI, 2017). Modalitas terapi ginjal yang paling umum digunakan ialah HD dan CAPD (Marshall, dkk, 2011). Rumah Sakit PGI Cikini merupakan salah satu rumah sakit swasta yang ada di DKI Jakarta yang menjadi pusat pelayanan penyakit ginjal. Rumah sakit ini memiliki pelayanan hemodialisis, CAPD, dan transplantasi ginjal bagi pasien penderita PGK.

Penatalaksanaan PGK bertujuan untuk mengoptimalkan fungsi ginjal yang ada serta mempertahankan keseimbangan fungsi ginjal secara maksimal sehingga dapat memperpanjang harapan hidup pasien (Prabowo, 2014). Terdapat beberapa faktor yang memengaruhi lama survival pasien PGK dengan terapi pengganti ginjal, antara lain karakteristik individu, faktor sosial dan ekonomi, faktor pengobatan, pemeriksaan indicator klinis, serta penyebab PGK (Sulistiawan, dkk, 2014; Bestari, 2015; Kurniawan dan Koesrini, 2019; Dogan, dkk, 2008; Krueger, dkk, dalam Kamerrer, 2007; Mau, dkk,
2008; Utami, 2015; Seidel, dkk, 2014; Nurchayati S, 2010; Chazot dan Jean, 2008; IRR, 2016; Hamid dan Azmi, 2009; Kaliahpan, 2010; Amin, 2014; Rivai, 2009; Nugrahani, 2007; Muttaqin, 2012).

Pada bidang kesehatan, untuk mengetahui ketahanan hidup seseorang sering digunakan analisis statistika yaitu dengan analisis survival. Dengan mengetahui ketahanan hidup serta faktorfaktor yang mempengaruhi PGK, kesadaran pasien akan pentingnya menjalani terapi pengganti ginjal akan meningkat. Tenaga kesehatan masyarakat juga dapat berperan dalam meningkatkan pengetahuan pasien ataupun masyarakat mengenai kesehatan ginjal, faktor-faktor yang mempengaruhi PGK, serta tindakan preventif terhadap PGK, sehingga derajat kesehatan masyarakat dapat meningkat dan kejadian PGK pun rendah. Penelitian ini perlu dilakukan untuk dapat mengetahui survival pasien PGK dengan modalitas terapi HD dan CAPD serta faktor-faktor yang berpengaruh terhadap survival pasien PGK yang menjalani terapi pengganti ginjal tersebut.

\section{METODE}

Penelitian ini bersifat observasional analitik dengan rancangan studi hystorical cohort yang dilaksanakan di Rumah Sakit PGI Cikini selama bulan Februari hingga April 2021. Dalam penelitian ini, kohort yang digunakan ialah pasien PGK dengan terapi pengganti ginjal berupa HD atau CAPD. Kriteria inklusi dalam penelitian ini, yaitu pasien PGK yang pertama kali menjalani terapi HD atau CAPD pada bulan Januari 2015 hingga Desember 2018 di Rumah Sakit PGI Cikini. Adapun 
kriteria eksklusi penelitian ini ialah pasien PGK yang pindah terapi dari HD menjadi CAPD dan sebaliknya serta pasien PGK yang menjalani terapi HD atau CAPD yang tidak tercatat umur, bulan dan tahun dimulainya terapi HD atau CAPD, serta bulan dan tahun meninggal dunia.

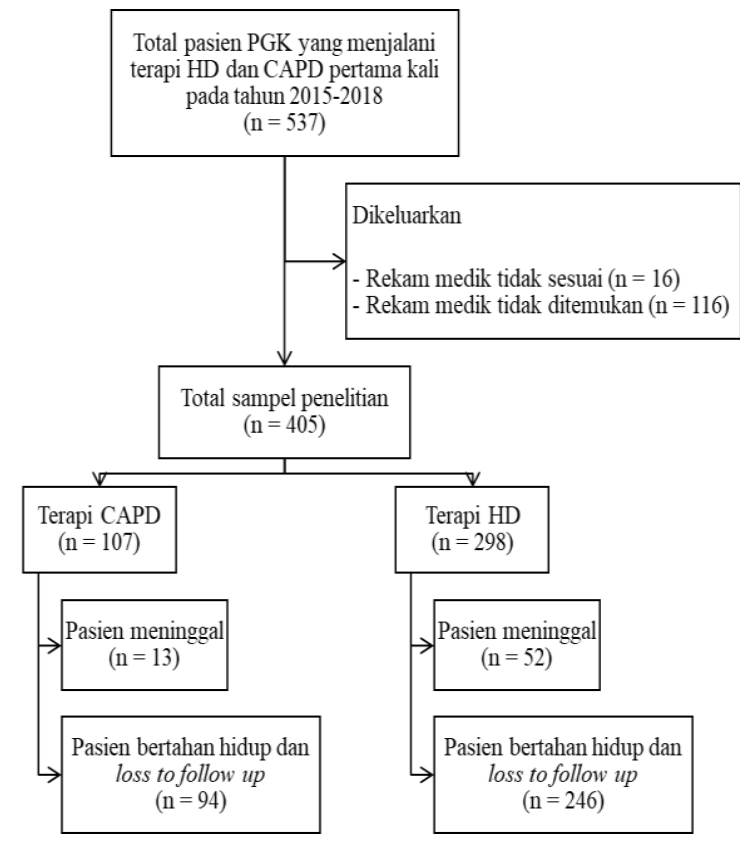

\section{Gambar 1. Diagram Alir Sampel Penelitian}

Pengambilan sampel penelitian dilakukan dengan menggunakan teknik total sampling dari total 537 pasien yang menjalani terapi pengganti ginjal. Sampel diambil dari seluruh pasien PGK yang menjalani terapi pengganti ginjal berupa HD atau CAPD yang tercatat pada rekam medis Rumah Sakit PGI Cikini periode 2015 - 2018 dan diamati hingga tahun 2020.

Tabel 1. Karakteristik Sampel Penelitian
Terdapat 16 data pasien yang tidak sesuai dengan nomor rekam medik serta 116 dokumen rekam medik pasien tidak bisa ditemukan. Data yang terkumpul kemudian akan dianalisis dengan analisis statistik deskriptif, analisis perbedaan fungsi survival, dan uji Cox Regression Propotional Hazard.

\section{HASIL PENELITIAN \\ Karakteristik Sampel Penelitian}

Berdasarkan data sekunder pasien PGK yang menjalani terapi HD dan CAPD pada tahun 2015-2018 di Rumah Sakit PGI Cikini, terdapat 405 orang sampel yang memenuhi kriteria inklusi penelitian dari total populasi sebesar 537 pasien. Adapun karakteristik dari sampel penelitian disajikan dalam tabel 1.

Berdasarkan hasil analisis ditunjukkan bahwa median umur sampel adalah 55 tahun dengan lebih dari sepertiga pasien PGK sampel berusia di atas 60 tahun. Sebagian besar sampel dalam penelitian ini berjenis kelamin lakilaki $(60,74 \%)$ dan berstatus pendidikan tinggi $(84,44 \%)$. Sebanyak $84,44 \%$ sampel berstatus menikah dan hanya $1,48 \%$ dari sampel yang telah bercerai. Mayoritas sampel menggunakan BPJS (60,74\%) dalam membiayai terapi pengganti ginjalnya. Selama waktu pengamatan, sebanyak $16 \%$ sampel yang meninggal dunia

\begin{tabular}{|c|c|c|}
\hline $\begin{array}{c}\text { Karakteristik Pasien HD dan } \\
\text { CAPD }\end{array}$ & Frekuensi & $\begin{array}{l}\text { Presentase } \\
\quad(\%)\end{array}$ \\
\hline Umur (Median; IQR) & & \\
\hline$<40$ & 58 & 14,32 \\
\hline $40-49$ & 83 & 20,49 \\
\hline
\end{tabular}


50-59

Jenis Kelamin

Perempuan

Laki-laki

Tingkat Pendidikan

Rendah (Tidak sekolah, SD, SMP)

Tinggi (SMA, Perguruan Tinggi)

\section{Status Pernikahan}

Belum Menikah

Menikah

Janda/Duda

Cerai

Jenis Asuransi Kesehatan

Tanpa Asuransi 86

21,23

BPJS

Asuransi Swasta

Asuransi Perusahaan

\section{Status Pasien}

Censored

\section{Gambaran Faktor Pengobatan}

Hampir tiga perempat (73,58\%) sampel dalam penelitian ini menjalani terap pengganti ginjal berupa HD. Di awal masa pengamatan, sebesar $76,05 \%$ pasien PGK melakukan terapi lebih dari 3 kali setiap minggunya, dengan catatan sebanyak 107 pasien PGK (26,42\%) yang menjalani terapi pengganti ginjal berupa CAPD melaksanakan terapi secara mandiri setiap hari sehingga total menjalani terapi sebanyak 7 kali tiap minggunya.

Tabel 2. Faktor Pengobatan, Indikator Klinis, dan Jumlah Diagnosis Sekunder pada Pasien PGK dengan Terapi Pengganti Ginjal HD dan CAPD

\section{Faktor Pengobatan}

\section{Frekuensi}

Presentase

(\%)

\section{Pengobatan}

Jenis Terapi Pengganti Ginjal

HD

CAPD
298 73,58

107 26,42

\section{Frekuensi Terapi}

HD 
1 kali

2 kali

3 kali

CAPD

7 kali

Indikator Klinis

Kadar Kreatinin (Median; IQR)

Normal

Tinggi

Kadar Albumin (Median; IQR)

Normal

Hipoalbumin

Kadar Hemoglobin (Median; IQR)

Tidak Anemia

Anemia

Jumlah Diagnosis Sekunder pada Pasien

\section{0}

1

2

3

4

5
8

1,98

89

21,98

201

49,62

107

26,42

8,$41 ; 6,1$

$$
5
$$

400

98,77

3,$1 ; 0,7$

103

25,43

302

74,57

8,$8 ; 2,2$

103

25,43

302

74,57

38

9,38

182

44,94

149

36,79

30

7,41

5

1,23

1

0,25

\section{Indikator Klinis}

Dilihat dari hasil pengukuran indikator klinis pasien saat pertama kali memulai terapi pengganti ginjal, pasien dengan hasil pengukuran normal pada ketiga indicator klinis sangat kecil. Hampir seluruh sampel (98,77\%) memliki kadar kreatinin yang tinggi, sedangkan tiga perempat $(74,57 \%)$ dari total sampel memiliki kadar albumin yang rendah dan mengalami anemia. Lebih dari setengah (57,53\%) pasien memiliki hasil pengukuran ketiga indicator klinis yang tidak normal.

\section{Penyebab PGK}

Hampir seluruh (90,62\%) pasien dengan terapi pengganti ginjal HD dan CAPD memiliki diagnosis sekunder selain didiagnosis utama dengan PGK. Terdapat 45 jenis penyakit yang menjadi diagnosis sekunder pada sampel penelitian. Berdasarkan hasil analisis deskriptif, didapatkan bahwa hipertensi merupakan jenis diagnosis sekunder terbanyak yang diderita oleh sampel (40\%), disusul dengan DM (25,04\%), dan pneumonia (7,9\%). Adapun jenis diagnosis sekunder lainnya seperti hepatitis, efusi pleura, dan dispepsia hanya memiliki proporsi sebesar 8,74\%. Mayoritas pasien HD dan CAPD memiliki 1 diagnosis sekunder (44,94\%). 


\section{Analisis Survival Pasien PGK dengan Terapi Pengganti Ginjal}

Survival pasien PGK dengan terapi pengganti ginjal HD dan CAPD diamati sampai dengan waktu 68 bulan yang merupakan waktu terpanjang sampel melakukan terapi pengganti ginjal hingga akhir tahun 2020.

Adapun rata-rata survival sampel penelitian ini ialah 50,7 bulan. Hasil analisis menunjukkan bahwa lebih dari setengah pasien PGK dengan terapi pengganti ginjal HD dan CAPD masih bertahan hidup sampai dengan akhir waktu penelitian dengan 3 years survival rate sebesar $69,91 \%$ dan 5 years survival rate di atas $50 \%$.

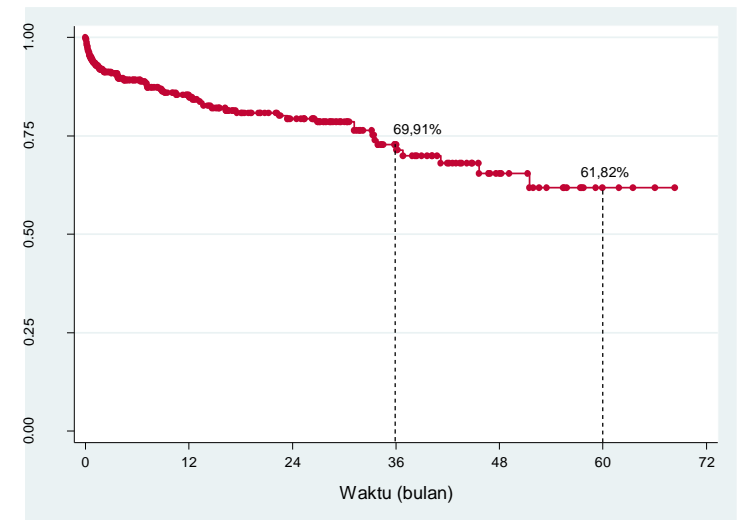

Gambar 2. Tingkat Survival Pasien PGK dengan Terapi Pengganti Ginjal HD dan CAPD di Rumah Sakit PGI Cikini Tahun 2015-2020

Berdasarkan hasil dari Uji Log Rank ditemukan bahwa terdapat perbedaan survival pasien PGK dengan terapi pengganti ginjal HD dan CAPD menurut kelompok umur, jenis asuransi kesehatan yang digunakan, status albumin, dan jumlah diagnosis sekunder $(\mathrm{p}<0,05)$. Tingkat survival pasien menurut jenis kelamin, tingkat pendidikan, dan jenis terapi cenderung sama. Tidak terdapat perbedaan survival berdasarkan yang bermakna secara statistic berdasarkan status pernikahan, frekuensi terapi, status kreatinin, dan status anemia.

\section{Analisis Faktor-Faktor yang Mempengaruhi Survival Pasien PGK dengan Terapi Pengganti Ginjal HD dan CAPD}

Faktor-faktor yang mempengaruhi tingkat survival pasien PGK dengan terapi pengganti ginjal HD dan CAPD di Rumah Sakit PGI Cikini dianalisis dengan Cox Regression Propotional Hazard dengan metode backward. Berdasarkan hasil analisis, faktor umur, jenis asuransi kesehatan yang digunakan, kadar albumin, dan jumlah diagnosis sekunder pada pasien berpengaruh yang bermakna secara statistik terhadap survival pasien PGK dengan terapi pengganti ginjal HD dan CAPD $(p<0,05)$. Namun, faktor lainnya seperti jenis terapi pengganti ginjal, frekuensi terapi, dan kadar kreatinin akan dilanjutkan ke tahap analisis multivariat karena memenuhi kriteria inklusi $\mathrm{p} \leq 0,2$.

Setiap umur pertama kali pasien menjalani terapi pengganti ginjal meningkat satu tahun berisiko mengalami kematian 1,027 kali (2,7\%) lebih tinggi. Dilihat dari jenis asuransi kesehatan, pasien yang tidak menggunakan asuransi kesehatan 0,298 kali (70,2\%) menurunkan risiko meninggal dibandingkan dengan pasien yang menggunakan BPJS untuk membiayai terapi pengganti ginjalnya.

Pasien dengan jenis terapi CAPD 0,597 kali (40,3\%) menurunkan risiko meninggal dibandingkan dengan pasien 
dengan jenis terapi HD. Berdasarkan frekuensi terapi, pasien yang melakukan HD ataupun CAPD satu kali lebih banyak per minggunya menurunkan risiko meninggal sebesar 0,893 kali (10,7\%).
Adapun peningkatan indikator klinis seperti kadar albumin sebesar 1 satuan (gr/dl) akan menurunkan risiko kematian sebesar 0,494 kali $(48,4 \%)$.

Tabel 3. Model Cox Regression Proportional Hazard Faktor-Faktor yang Mempengaruhi Survival Pasien PGK dengan Terapi Pengganti Ginjal HD dan CAPD

\begin{tabular}{|c|c|c|c|c|c|c|}
\hline \multirow{2}{*}{ Faktor } & \multicolumn{3}{|c|}{ Model Awal } & \multicolumn{3}{|c|}{ Model Akhir } \\
\hline & HR & $95 \%$ CI & $p$-value & HR & $95 \%$ CI & p-value \\
\hline Umur & 1,019 & $\begin{array}{l}0,997- \\
1,041\end{array}$ & 0,099 & 1,024 & $\begin{array}{l}1,003- \\
1,046\end{array}$ & 0,027 \\
\hline $\begin{array}{l}\text { Jenis Asuransi } \\
\text { Kesehatan }\end{array}$ & & & & & & 0,010 \\
\hline BPJS & Reff & & & Reff & & \\
\hline Tanpa Asuransi & 0,340 & $\begin{array}{l}0,135- \\
0,856\end{array}$ & 0,022 & 0,312 & $\begin{array}{l}0,125- \\
0,781\end{array}$ & 0,013 \\
\hline Asuransi Swasta & 0,315 & $\begin{array}{l}0,076- \\
1,312\end{array}$ & 0,113 & 0,267 & $\begin{array}{l}0,064- \\
1,102\end{array}$ & 0,068 \\
\hline $\begin{array}{l}\text { Asuransi } \\
\text { Perusahaan }\end{array}$ & 0,180 & $\begin{array}{l}0,024- \\
1,310\end{array}$ & 0,090 & 0,193 & $\begin{array}{l}0,027- \\
1,397\end{array}$ & 0,103 \\
\hline $\begin{array}{l}\text { Jenis Terapi } \\
\text { Pengganti Ginjal }\end{array}$ & & & & & & \\
\hline HD & Reff & & & & & \\
\hline CAPD & 0,925 & $\begin{array}{l}0,075- \\
11,417\end{array}$ & 0,952 & & & \\
\hline Frekuensi Terapi & 0,913 & $\begin{array}{l}0,522- \\
1,597\end{array}$ & 0,749 & & & \\
\hline Kadar Kreatinin & 0,986 & $\begin{array}{l}0,927- \\
1,048\end{array}$ & 0,645 & & & \\
\hline Kadar Albumin & 0,540 & $\begin{array}{l}0,345- \\
0,846\end{array}$ & 0,007 & 0,480 & $\begin{array}{l}0,310- \\
0,742\end{array}$ & 0,001 \\
\hline $\begin{array}{l}\text { Jumlah Diagnosis } \\
\text { Sekunder pada } \\
\text { Pasien }\end{array}$ & 1,307 & $\begin{array}{l}0,987- \\
1,731\end{array}$ & 0,062 & & & \\
\hline
\end{tabular}

Berdasarkan tabel 3 terlihat bahwa hanya variabel kadar albumin $(p=0,007)$ yang berpengaruh signifikan secara statistic setelah pengaruh variabel lainnya dikontrol. diperoleh tiga faktor yang berpengaruh signifikan secara statistic yaitu kadar albumin ( $\mathrm{p}=0,001)$, umur $(\mathrm{p}=$ $0,027)$, dan jensi asuransi kesehatan $(\mathrm{p}=$ 0,010). Terdapat total lima model Cox Regression Proportional Hazard yang diuji 
sampai didapatkan model terbaik dalam penelitian ini. Dari hasil analisis didapatkan bahwa setiap setiap peningkatan kadar albumin pasien sebesar $1 \mathrm{gr} / \mathrm{dl}$ akan menurunkan risiko kematian 0,48 kali (52\%). Peningkatan umur pertama kali pasien menjalani terapi pengganti ginjal sebanyak satu tahun akan meningkatkan risiko kematian 1,024 kali $(2,4 \%)$. Sedangkan, pasien yang menggunakan biaya pribadi 0,34 kali (66\%) menurunkan risiko mengalami kematian dibandingkan pasien dengan BPJS dan terdapat pengaruh yang signifikan secara statistic $(p=0,0123)$.

\section{DISKUSI}

Ketahanan hidup pasien HD dan CAPD di Rumah Sakit PGI Cikini cukup tinggi dikarenakan hingga akhir waktu pengamatan, setengah dari sampel yang berpartisipasi masih tetap bertahan hidup. Pada tahun ketiga, survival pasien masih tinggi yaitu sebesar $69,91 \%$ dan turun menjadi $61,82 \%$ pada tahun kelima. Hasil serupa juga ditemukan pada pasien dengan hemodialisis di Jawa Barat yang memiliki three years survival rate sebesar $62,1 \%$ (Afiatin, dkk, 2020).

Hampir $50 \%$ pasien PGK dengan terapi pengganti ginjal mengalami kematian di tiga bulan pertama pelaksanaan terapi pengganti ginjal. Sembilan puluh hari pertama setelah dimulainya dialisis dipandang sebagai masa kritis. Hal itu disebabkan karena pasien perlu beradaptasi secara fisik dan psikologis dengan prinsip perawatan yang dijalani seumur hidup ini (Noordzij dan Jager, 2014). Hasil penelitian oleh Bradbury, dkk (2007) menyatakan bahwa tingginya angka mortalitas pada 120 hari pertama perawatan dialisis dipengaruhi oleh beberapa factor, antara lain usia yang lebih tua, akses vaskular kateter, kadar albumin dan fosfor yang rendah, serta perawatan nefrologi predialisis yang tidak memadai.

Penurunan tingkat survival pasien PGK dengan terapi pengganti ginjal HD dan CAPD dapat disebabkan oleh berbagai hal. Terdapat tiga faktor yang memiliki pengaruh bermakna secara statistik terhadap tingkat survival pasien PGK dengan terapi pengganti ginjal HD dan CAPD di Rumah Sakit PGI Cikini, yaitu kadar albumin, umur pertama kali melakukan terapi pengganti ginjal, dan jenis asuransi kesehatan.

Kadar albumin berpengaruh secara signifikan terhadap survival pasien PGK setelah dikontrol oleh faktor umur dan jenis asuransi kesehatan. Dalam penelitian ini didapatkan tiap kenaikan kadar albumin sebesar $1 \mathrm{gr} / \mathrm{dl}$, maka risiko kematian turun 0,48 kali (52\%) dan pengaruh kadar albumin bermakna secara statistik ( $\mathrm{HR}=0,480 ; 95 \% \mathrm{CI}=0,310-0,742$; $\mathrm{p}=0,001)$. Kadar albumin yang rendah merupakan prediktor kematian pada pasien yang menjalani dialisis (Bradbury, dkk, 2007; Capelli, dkk, 2008; dan Kato, dkk, 2010).

Sebanyak 74,57\% sampel dalam penelitian ini menderita hipoalbuminemia (kadar albumin $<3,5$ gr/dl). Hipoalbuminemia merupakan sebuah indikator malnutrisi yang juga merupakan prediktor independen yang kuat dari kematian pada pasien PGK dengan terapi pengganti ginjal. Kato, Castro dan Natarajan (2013) menyatakan risiko kematian tinggi ada pada kelompok pasien 
HD dengan kadar albumin serum $\leq 3,8$ gr/dl. Hal tersebut diperkuat dengan hasil penelitian oleh Ebrahimi, dkk (2019) yang memaparkan bahwa untuk setiap unit peningkatan albumin serum, waktu survival pasien HD meningkat sekitar 23\%.

Rendahnya kadar albumin dapat dipengaruhi oleh asupan protein harian yang rendah. Namun, kadar albumin harus digunakan dengan hati-hati sebagai penanda nutrisi untuk pasien dialisis karena rendahnya kadar protein pada pasien dialisis juga berhubungan dengan malnutrisi, peradangan, serta dengan komplikasi lain (Shao, Wang, dan Parameswaran, 2016; Alfonso, dkk, 2015; Kato, Castro, dan Natarajan, 2013; Kamal dan Nour, 2016; Latifah, Suswardany, dan Kusumawati, 2012).

Penanganan yang komperhensif terhadap kebutuhan nutrisi pasien dialysis seperti peningkatan asupan makanan, konsumsi protein, asupan vitamin, pembatasan cairan, dan suplai energi harus ditangani dengan baik untuk mencegah keadaan katabolik yang dapat memastikan keberhasilan terapi dengan dialisis dalam jangka panjang (Leon, dkk, 2006; Schmiker dalam Kiebalo, dkk, 2020). Peradangan dan kondisi komorbiditas juga dapat menekan nafsu makan yang merusak upaya untuk meningkatkan status gizi pasien. Sehingga, suplementasi nutrisi dapat menjadi solusi yang bermanfaat untuk meningkatkan nutrisi pasien (Kaysen, 2003).

Faktor umur pertama kali melakukan terapi pengganti ginjal juga memiliki pengaruh yang signifikan terhadap survival pasien PGK setelah dikontrol oleh kadar albumin. Tiap kenaikan 1 tahun umur pasien saat memulai terapi pengganti ginjal maka risiko kematian meningkat 1,024 kali $(2,4 \%)$ (HR=1,024; 95\% CI=1,003 - 1,046; $\mathrm{p}=0,027)$. Pasien yang berumur di atas 60 tahun memiliki proporsi terbesar dalam penelitian ini $(37,78 \%)$. Wagner, dkk (2011) menyatakan bahwa umur yang lebih tua saat menjalani terapi pengganti ginjal dikaitkan secara independen dalam meningkatkan risiko kematian pasien PGK.

Dalam penelitian oleh Valdivia, dkk (2013) yang menyatakan bahwa tingkat survival pasien PGK yang menjalani terapi pengganti ginjal dengan usia di atas 60 tahun adalah 0\%. Hal tersebut disebabkan oleh semakin bertambah usia, maka fungsi ginjal semakin menurun dan hal tersebut berhubungan dengan penurunan kecepatan ekskresi glomerulus serta memburuknya fungsi tubulus. Sehingga, semakin tua usia pasien saat menjalani terapi pengganti ginjal mengakibatkan ketahanan hidup pasien semakin rendah (Pranandari dan Supadmi (2015) .

Dalam suatu penelitian oleh Verberne, dkk (2016), dipaparkan bahwa pada pasien dengan usia $\geq 80$ tahun, tidak lagi terdapat keuntungan terhadap kelangsungan hidup yang signifikan secara statistik dengan menggunakan terapi pengganti ginjal dibandingkan dengan terapi konservatif. Sehingga, diperlukan pertimbangan dan studi lebih lanjut terhadap pengambilan keputusan untuk pelaksanaan terapi pengganti ginjal pada penderita PGK usia lanjut yang meliputi dampak terapi pengganti ginjal terhadap ketahanan hidup pasien baik dari segi keuangan maupun kualitas hidup 
yang didapatkan. Selain itu, pelaksanaan terapi pengganti ginjal sebaiknya dimulai sejak umur penderita PGK lebih muda, hal tersebut dikarenakan ada penurunan tajam dalam kelangsungan hidup dengan bertambahnya usia (Steenkamp, Pyarta, dan Fraser, 2018; Hamilton, dkk, 2017).

Diperlukan pula pencegahan terutama pada masyarakat dengan usia lanjut untuk mencegah terjadinya PGK, yaitu dengan pemberian edukasi serta mengoptimalkan fungsi dari Posbindu PTM bagi para lansia. Posibindu PTM dapat meningkatkan self-awareness para lansia melalui kegiatan pengukuran berat badan, tekanan darah, dan pemeriksaan gula darah secara rutin. Dengan dioptimalkannya fungsi dan kegiatan pada Posbindu PTM maka kesehatan lansia dapat terpantau dengan baik dan dapat menghindari terjadinya PGK di masa mendatang.

Jenis asuransi kesehatan yang digunakan pasien untuk membiayai terapi pengganti ginjal juga berhubungan secara statistik dengan survival pasien berdasarkan overall p-value yang lebih rendah dari 0,05. Hasil penelitian ini didukung oleh Valdez-Ortiz, dkk (2018) yang menyatan bahwa terdapat hubungan antara status pembayaran pasien dengan kematian pasien PGK. Hampir seluruh pasien dalam penelitian ini menggunakan asuransi (BPJS, asuransi swasta, dan asuransi perusahaan) untuk membiayai terapi pengganti ginjalnya.

Pasien dengan asuransi kesehatan memiliki keuntungan berupa tidak perlu mengeluarkan biaya tambahan untuk menjalani terapi pengganti ginjal, berbeda dengan pasien yang harus membayar layanan dengan out of pocket (OOP) yang harus menanggung semua biaya dialisis secara normal. Pembayaran terapi pegganti ginjal secara OOP memungkinkan pasien tidak patuh untuk melakukan terapi secara rutin sesuai jadwal yang dapat meningkatkan mortalitas, diakibatkan oleh ketidakpastian adanya biaya untuk membayar terapi tersebut (Muzasti, 2011). Namun, dalam penelitian ini ditemukan bahwa risiko kematian pasien HD dan CAPD yang membayar OOP lebih rendah jika dibandingkan dengan pasien yang menggunakan asuransi perusahaan. Hal ini dapat disebabkan oleh kemampuan ekonomi pasien yang membayar secara OOP lebih tinggi, sehingga mampu melaksanakan terapi secara teratur. Seperti dalam Fitriani (2009) yang menyatakan bahwa salah satu faktor yang mempengaruhi kepatuhan menjalankan hemodialisis ialah faktor ekonomi pasien.

Selain itu, kemampuan ekonomi pasien tanpa asuransi kesehatan bisa dikatakan cukup tinggi karena mampu menjalani terapi pengganti ginjal di Rumah Sakit Cikini yang merupakan rumah sakit tingkat swasta. Namun, kemampuan ekonomi tidak diukur dalam penelitian ini sehingga perlu dibuktikan secara lanjut di kemudian hari.

Di sisi lain, faktor jenis terapi pengganti ginjal tidak berpengaruh secara statistik terhadap tingkat survival pasien PGK dengan terapi pengganti ginjal HD dan CAPD. Hal ini sejalan dengan hasil penelitian oleh Zahara (2016) yang menyatakan bahwa jenis terapi pengganti ginjal (HD dan CAPD) tidak mempengaruhi lama survival pasien PGK $(p=0,226)$. Tidak adanya perbedaan survival 
antara HD dan CAPD dapat disebabkan oleh perbedaan usia, ras, penyebab PGK, penyakit penyerta, kurangnya waktu follow-up, waktu dimulainya terapi pengganti ginjal, serta faktor lainnya (Johansen, dkk, 2009; Ganesh, dkk, 2003; Xue, dkk, 2002).

Selain itu, tidak berbedanya survival pasien dengan terapi HD dan CAPD dalam penelitian ini menandakan bahwa kedua jenis modalitas terapi memberikan hasil yang sama terhadap survival pasien PGK. Seperti yang dijelaskan dalam penelitian oleh Sinnakirouchenan dan Holley (2011) bahwa keuntungan ketahanan hidup yang didapatkan pada terapi PD sama saja dengan HD setelah satu hingga dua tahun setelah pelaksanaan terapi pengganti ginjal yang juga dipengaruhi oleh adanya penyakit komorbid dan usia.

Baik terapi HD maupun CAPD memiliki keunggulan dan kelemahannya masing-masing yang perlu diinformasikan kepada pasien PGK sebelum melaksanakan terapi pengganti ginjal. Sehingga, pemberian edukasi dan informasi kepada pasien terhadap pemilihan modalitas terapi sangat diperlukan untuk pengambilan keputusan dan umunya sangat tergantung oleh masukan dan dorongan dari dokter (Sinnakirouchenan dan Holley, 2011). Bagi instansi kesehatan, terutama dokter yang menangani pasien PGK sangat perlu untuk menginformasikan terkait kelemahan dan keunggulan terapi kepada pasien dan keluarganya, berdasarkan beberapa indikator terkait gaya hidup dan kondisi sosial demografi pasien, sehingga pemilihan modalitas terapi dapat sesuai dengan kebutuhan pasien dan terapi nantinya dapat berjalan dengan baik dan optimal.

Pasien PGK dengan CAPD di Rumah Sakit PGI Cikini melaksanakan terapi sebanyak 7 kali setiap minggunya, berbeda dengan pasien PGK dengan HD yang frekuensi terapinya berbeda yaitu sebanyak 1-3 kali per minggunya. Adanya hubungan antara jenis terapi dengan frekuensi terapi dapat menyebabkan faktor jenis terapi pengganti ginjal tidak berpengaruh secara signifikan terhadap survival pasien PGK dengan terapi pengganti pada penelitian ini.

Kadar kreatinin tidak mempengaruhi survival pasien PGK yang menjalani terapi pengganti ginjal dalam penelitian ini ( $\mathrm{HR}=0986$; 95\% CI=0,927 1,048; $\mathrm{p}=0,645)$. Hal tersebut sejalan dengan penelitian oleh Garcia-Garcia, dkk (2007) yang menyatakan bahwa tidak ditemukan hubungan antara kadar kreatinin dengan kelangsungan hidup pasien gagal ginjal $(p=0,40)$. Hampir seluruh pasien memiliki kadar kreatinin yang tinggi $(>1,5 \mathrm{mg} / \mathrm{dl})$ dengan median 8,41 mg/dl. Sejalan dengan penelitian oleh Park, dkk (2018) yang menyatakan kadar kreatinin yang lebih rendah merupakan indikator fungsi ginjal yang lebih baik pada pasien PGK. Meningkatnya kadar kreatinin pada pasien PGK dapat disebabkan oleh konsumsi daging sapi yang terlalu sering serta obatobatan seperti vitamin C, antibiotik golongan sefalosporin, dan aminoglikosid. Sehingga, dapat dipertimbangakan untuk pasien PGK agar mengurangi konsumsi makanan atau obat-obatan tersebut (Indriasari, 2009).

Kadar hemoglobin juga merupakan indikator klinis yang tidak berpengaruh 
terhadap survival PGK dengan terapi pengganti ginjal. Hasil penelitian ini sejalan dengan Wong, dkk (2007) yang memaparkan bahwa kadar hemoglobin tidak berepengaruh secara statistic terhadap survival pasien PGK $(p=0,740)$. Tidak adanya pengaruh yang signifikan antara kadar hemoglobin dan survival pasien PGK dapat disebabkan oleh adanya kemungkinan pasien PGK mengalami inflamasi, malnutrisi, ataupun keadaan lainnya menyebabkan tidak berpengaruhnya kadar hemoglobin dengan survival pasien PGK dengan dialysis (Levin, 2002).

Jenis kelamin pasien PGK dengan terapi pengganti ginjal secara statistic tidak berpengaruh terhadap survival pasien. Seperti halnya penelitian oleh Wong, dkk (2018) yang menyatakan bahwa jenis kelamin tidak berpengaruh terhadap survival pasien HD dan PD $(p=0,4)$. Hal ini dapat disebabkan oleh perilaku kesehatan maupun hormon pasien (Beltrán-Sánchez, Finch, Crimmins, 2015). Jumlah pasien PGK dengan terapi pengganti ginjal di RS PGI Cikini mayoritas berjenis kelamin lakilaki (60,74\%). Banyaknya proporsi pasien laki-laki dapat disebabkan oleh gaya hidup yang cenderung tidak sehat dibandingkan dengan perempuan. Pria dengan PGK memiliki kebiasaan makan yang lebih buruk dan kurang patuh dengan pantangan makanan serta kebiasaan merokok dan juga minum alkohol maupun minuman berenergi pada laki-laki sehingga PGK lebih banyak terjadi pada pasien berjenis kelamin laki-laki (Jones, 2007, dalam Arhamawati, Saryono, Awaludin, 2019).
Jumlah diagnosis sekunder juga merupakan faktor yang tidak berpengaruh terhadap survival pasien PGK yang menjalani terapi pengganti ginjal. Dalam penelitian ini, diagnosis sekunder dipakai sebagai proksi dari penyebab PGK pada pasien HD dan CAPD. Hasil penelitian ini didukung oleh Lee, dkk (2018) yang menyatakan tidak terdapat hubungan dan perbedaan yang signifikan antara penyakit penyerta terhadap kelangsungan hidup pasien PGK stadium akhir. Ketidakbermaknaan secara statistic tersebut kemudian berubah menjadi bermakna setelah disesuaikan dengan faktor sosiodemografi dan variabel klinis. Sehingga, diperlukan adjustment terhadap faktor diagnosis sekunder untuk melihat pengaruhnya terhadap survival pasien PGK dengan terapi pengganti ginjal.

Tingkat pendidikan dan status pernikahan juga merupakan faktor yang tidak berpengaruh terhadap survival pasien PGK dengan terapi pengganti ginjal. Sejalan dengan penelitian oleh Sanabria, dkk (2008) yang menyatakan tingkat pendidikan pada pasien PGK tidak mempengaruhi survival pasien. Hampir 85\% pasien PGK berpendidikan tinggi. Tingkat pendidikan yang tinggi berhubungan dengan status pekerjaan seseorang yang juga dapat mempengaruhi gaya hidup tidak sehat, seperti tidak selektif dalam memilih makanan dan jam kerja lembur yang padat. Hal ini dapat dapat menyebabkan risiko terkena PGK yang lebih besar dan mempengaruhi faktor tingkat pendidikan tidak berpengaruh secara signifikan terhadap survival pasien PGK dengan terapi pengganti ginjal (Utami, 2015). 
Lebih dari tiga perempat pasien berstatus menikah saat pertama kali menjalani terapi pengganti ginjal. Banyak penelitian menunjukkan bahwa pasien yang belum menikah dikaitkan dengan peningkatan risiko kematian pada pasien PGK (Manzoli, dkk, 2007; Ikeda, dkk, 2007; Kaplan dan Kronick, 2006). Namun, tidak didapatkan pengaruh yang signifikan secara statistic antara status pernikahan dan survival pasien. Hal ini dapat disebabkan oleh karakteristik pasien, yang mana pada kelompok pasien yang menikah, paling banyak yang berusia di atas 40 tahun, sedangkan pada kelompok yang belum menikah hamper seluruhnya berada di kelompok umur di bawah 40 tahun. Tidak berpengaruhnya faktor status pernikahan juga dapat disebabkan oleh tidak adanya informasi mengenai kualitas perkawinan dan transisi perkawinan dalam penelitian ini yang berkaitan dengan peningkatan risiko kematian pada pasien HD (Kimmel, dkk, 2000 dan Peterson, dkk, 1995, dalam Tanno, dkk, 2013).

\section{SIMPULAN}

Tingkat survival pasien PGK dengan terapi pengganti ginjal HD dan CAPD di Rumah Sakit PGI Cikini cukup tinggi, yaitu sebesar $69,91 \%$ pada tahun ketiga dan $61,82 \%$ pada tahun kelima. Faktor-faktor yang mempengaruhi tingkat survival pasien PGK dengan terapi pengganti ginjal HD dan CAPD di Rumah Sakit PGI Cikini adalah kadar albumin, umur pertama kali melakukan terapi pengganti ginjal, serta jenis asuransi kesehatan.

\section{SARAN}

Perlunya penanganan yang komperhensif terhadap kebutuhan nutrisi dan penanganan peradangan pada pasien dialisis untuk meningkatkan kadar albumin pasien. Pemberian edukasi kepada masyarakat mengenai nutrisi serta asupan protein yang seimbang dan tepat diperlukan sebagai Tindakan preventif terhadap terjadinya kerusakan pada ginjal. Diperlukan juga pertimbangan dan studi lebih lanjut terhadap pengambilan keputusan untuk pelaksanaan terapi pengganti ginjal pada penderita PGK usia lanjut serta mengoptimalkan fungsi dari Posbindu PTM bagi para lansia sehingga kesehatan lansia dapat dimonitor dengan baik. Selain itu, bagi dokter yang menangani pasien PGK perlu untuk mengedukasi dan menginformasikan pasien PGK sebelum melaksanakan terapi pengganti ginjal mengenai kelemahan dan keunggulan modalitas terapi yang ada berdasarkan beberapa indikator terkait gaya hidup dan kondisi sosial demografi pasien.

\section{UCAPAN TERIMA KASIH}

Penulis mengucapkan terima kasih kepada keluarga, pembimbing, penguji, rekan-rekan, seluruh pegawai Rekam Medis Rumah Sakit PGI Cikini serta seluruh pihak yang tidak dapat disebutkan satu persatu yang telah mendukung pelaksanaan penelitian ini.

\section{DAFTAR PUSTAKA}

Alfonso, A, Castillo, R, Gomez, JF \& Negrillo, A. (2015). Evaluation of nutritional biochemical parameters in Haemodialysis patients over a ten- 
year period. West Indian Med J. Vol. 64(3):213-7.

Afiatin, Agustian, D, Wahyudi, K, Riono \& Roesli, RMA. (2020). Survival Analysis of Chronic Kidney Disease Patients with Hemodialysis in West Java. Indonesia, Year 2007-2018. Majalah Kedokteran Bandung. Vol. 52 (3).

Amin, NU, dkk. (2014). Evaluating Urea and Creatinine Levels in Chronic Renal Failure Pre and Post Dialysis: A Prospective Study. Jurnal Cardiovascular Disease. Vol. 2(2). ISSN: 2330-4596.

Arhamawati, S, Saryono \& Awaludin. (2019). Correlation between the levels of urea serum, creatinine, and haemoglobin with fatigue in patient with Chronic Kidney Disease at Haemodialisa Unit, dr. R. Goeteng Taroenadibrata General Hospital Purbalingga. Journal of Bionursing Vol 1(1).

Bestari, AW. (2015). Faktor yang Berhubungan dengan Kualitas Hidup Penyakit Gagal Ginjal Kronis (PGK) Hemodialisis Berdasarkan WHOQOL-BREF (Penelitian di Instalasi Hemodialisis RSU Haji Surabaya Tahun 2015). Surabaya: Universitas Airlangga.

Bikbov, B, GBD Chronic Kidney Disease Collaboration. (2020). Global, regional, and national burden of chronic kidney disease, 1990-2017: a systematic analysis for the Global
Burden of Disease Study 2017. The

Lancet. $\quad 395: \quad$ 709-33. doi: /doi.org/10.1016/ S01406736(20)30045-3.

Bradbury, BD, Fissell, RB, Albert, JM, Anthony, MS, Critchlow, CW, Pisoni, RL, Port, FK \& Gilllespie, BW. (2007). Predictors of early mortality among incident US hemodialysis patients in the Dialysis Outcomes and Practice Patterns Study (DOPPS). Clin J Am Soc Nephrol. 2:89-99.

Capelli, JP \& Kushner, H. (2008). Correlates affecting survival in chronic hemodialysis patients: the combined impact of albumin and high hemoglobin levels on improving outcomes, local and national results. Hemodial Int. 12:450-462.

Centers for Disease Control and Prevention. (2017). National Chronic Kidney Disease Fact Sheet, 2017. USA: CDC.

Center for Disease Control and Prevention. (2019). Chronic Kidney Disease in the United States, 2019. US: CDC.

Chazot, C, Jean, G. (2008). Advantages and Challenges of Increasing Dialysis Duration and Frequency: Effects of Dialysis Time and Frequency on Survival. Nature Clinical Practice Nephrology. Vol. 5(1). pp: 34-44.

Dogan, S, Ekiz, S, Yucel, L, Ozturk, S \& Kazaneioglu, R. (2008). Relation of Demographic clinic and Biochemical parameter to peritoneal dialysis. 
Turkey Journal of Renal Care. Vol. 34(1). pp: 5-8.

Ganesh SK, Hulbert-Shearon T, Port FK, Eagle K, Stack AG. (2003). Mortality differences by dialysis modality among incident ESRD patients with and without coronary artery disease. $J$ Am Soc Nephrol. 14:415-24.

Hamid, AJ \& Azmi, MT. (2009). Predictor of Survival Among and Stage Renal Failure Patients Undergoing Dialysis Treatment in Pahang From 2000 to 2004. Jurnal of Comunity Health. Vol 15 (1).

Hamilton, AJ, Casula, A, Ben-Shlomo,Y, dkk. (2018). The clinical epidemiology of young adults starting renal replacement therapy in the UK: presentation, management and survival using 15 years of UK Renal Registry data. Nephrol Dial Transplant. Vol. 33. hh: 356-364.

Ikeda, A, Iso, $\mathrm{H}$, Toyoshima, $\mathrm{H}$, dkk. (2007). Marital status and mortality among Japanese men and women: the Japan Collaborative Cohort Study. BMC Public Health, 7(1). doi:10.1186/1471-2458-7-73.

Indonesia Renal Registry. (2015). 8th Report Of Indonesian Renal Registry. Jakarta: IRR.

Indriasari, D. (2009). 100\% Sembuh Tanpa Dokter. Yogyakarta: Galangpress.

Johansen KL, Zhang R, Huang Y, dkk. (2009). Survival and hospitalization among patients using nocturnal and short daily compared to conventional hemodialysis: A USRDS study. Kidney Int. 76:984-90.

Kaliahpan, P. (2010). Perubahan Kadar Albumin dan Kreatinin Sebelum dan Sesudah Hemodialisis pada Penderita Gagal Ginjal di RSUD Dr. Pirngadi. Medan: USU.

Kamal, AL, Shafei, N \& Nour, A. (2016). $\mathrm{CBC}$, serum proteins, and Immunoglobulins in chronic hemodialysis patients with or without pruritus in Egypt. Biochem Anal Biochem. 2016;05(01):1-7.

Kamerer, J, Garry, G, Hartigan, M, Carter, B \& Erlich L. (2007). Adherence in Patients On Dialysis: Strategies for Succes. Nephrology Nursing Journal. Vol 34(5). pp: 479-485.

Kaplan, R. M. (2006). Marital status and longevity in the United States population. Journal of Epidemiology \& Community Health, 60(9), 760-765. doi:10.1136/jech.2005.037606

Kato, A, Takita, T, Furuhashi, M, Maruyama, Y \& Hishida. (2010). A: Comparison of serum albumin, Creactive protein and carotid atherosclerosis as predictors of 10year mortality in hemodialysis patients. Hemodial Int. 14:226-232.

Kato, M, Castro, NC \& Natarakan, R. (2013). MicroRNAs: potentialmediatorsandbiomarkers of diabeticcomplications. Free Radic Biol Med. 2013;64:85-94. 
Kaysen, GA. (2003). Serum albumin concentration in dialysis patients: Why does it remain resistant to therapy?. Kidney International. Vol. 64(87). Hh: S92-S98.

Kementerian Kesehatan Republik Indonesia. (2018). Riset Kesehatan Dasar 2018. Jakarta: Kemenkes RI.

Kementerian Kesehatan Republik Indonesia. (2019). Buku Pedoman Manajemen Penyakit Tidak Menular. Jakarta: Kemenkes RI.

Khan, YH, Mallhi, TH, Sarriff, A, Khan, AH \& Tanveer, N. (2018). Prevalence of Chronic Kidney Disease in Asia: A Systematic Review of PopulationBased Studies. Journal of the College of Physicians and Surgeons Pakistan. Vol. 28 (12). pp: 960-966.

Kiebalo, T, dkk. (2020). Nutritional Status in Peritoneal Dialysis: Nutritional Guidelines, Adequacy and the Management of Malnutrition. Nutrients. $\quad 12, \quad 1715$; doi:10.3390/nu12061715.

Latifah, I, Suswardany, DL \& Kusumawati, Y. (2012). Hubungan Antara Kadar Hemoglobin, Kadar Albumin, Kadar Kreatinin Dan Status Pembayaran Dengan Kematian Pasien Gagal Ginjal Kronik Di RSUD Dr. Moewardi Surakarta.UMS: Surakarta.

Lee, W, Lee, Y, Li, L, dkk. (2018). The Number of Comorbidities Predicts Renal Outcomes in Patients with Stage
3-5 Chronic Kidney Disease. J. Clin. Med. 7, 493; doi:10.3390/jcm7120493.

Leon, JB, Mach, S, Majerle, A, dkk. (2006). Improving Albumin Levels Among Hemodialysis Patients: A Community-Based Randomized Controlled Trial. American Journal of Kidney Diseases. Vol. 48(1). hh: 28-36.

Levin, A. (2002). The relationship of haemoglobin level and survival: direct or indirect effects?. Nephrol Dial Transplant. Vol.17. hh: 8-13.

Manzoli, L, Villari, P, M Pirone, G, \& Boccia, A. (2007). Marital status and mortality in the elderly: A systematic review and meta-analysis. Social Science E Medicine, 64(1), 7794. doi:10.1016/j.socscimed.2006.08.03 1.

Marshall, MR, Hawley, CM, Kerr, PG, Polkinghorne, KR, Marshall, RJ, Agar, JW \& McDonald, SP. (2011). Home hemodialysis and mortality risk in Australian and New Zealand populations. Am J Kidney Dis. Vol. 58(5). pp: 782-93. doi: 10.1053/j.ajkd.2011.04.027.

Mau, LW, Chiu, HC, Chang, PY, Hwang, SC \& Hwang, SJ. (2008). HealthRelated Quality of Life In Taiwanese Dialysis Patients: Effects Of Dialysis Modality. Kaohsiung J Med Sci. Vol 24(9).

Muhani, N \& Sari, N. (2020). Analisis Survival pada Penderita Gagal Ginjal Kronik dengan Komorbiditas 
Diabetes Melitus. Media Kesehatan Masyarakat Indonesia 16(2), 216-224. doi: 10.30597/mkmi.v16i2.9047.

Muttaqin, A \& Kumala, S. (2012). Asuhan Keperawatan Gangguan Sistem Perkemihan. Jakarta: Salemba Medika.

Noordzij, M \& Jager, KJ. (2014). Increased mortality early after dialysis initiation: a universal phenomenon. Kidney International. Vol. 85 (1). pp: 12-14.

Nugrahani, A. (2007). Hubungan Asupan Protein Terhadap Kadar Urea Nitrogen, Kreatinin, dan Albumin Darah Pasien Penyakit Ginjal Kronik Yang Menjalani Hemodialisis di RSUP Dr. Sardjito Yogyakarta. Yogyakarta: UGM.

Nurchayati, S. (2010). Analisis Faktorfaktor yang Berhubungan dengan Kualitas Hidup Pasien Gagal Ginjal Kronik yang menjalani Hemodialisa di Rumah Sakit Islam Fatimah Cilacap dan RS Umum Daerah Banyumas. Depok: UI.

Park, JM, Lee, J.H, Jang, HM, dkk. (2018). Survival in patients on hemodialysis: Effect of gender according to body mass index and creatinine. PLOS ONE. Vol. 13(5), e0196550. doi:10.1371/journal.pone.01 96550).

Prabowo, Eko \& Pranata, AE. (2014). Asuhan Keperawatan Sistem Perkemihan. Yogyakarta: NuhaMedika.
Pranandari, R \& Supadmi, W. (2015). Faktor Risiko Gagal Ginjal Kronik Di Unit Hemodialisis Rsud Wates Kulon Progo. Majalah Farmaseutik. Vol. 11(2).

Pusat Data dan Informasi Kementerian Kesehatan Republik Indonesia. (2017). Infodatin: Situasi Penyakit Ginjal Kronis. Jakarta: Pusdatin Kemenkes RI.

Rivai, AT. (2009). Status Albumin Serum Pasien Penyakit Ginjal Kronik yang Menjalani Hemodialisis di Rumah Sakit Cipto Mangunkusumo pada Bulan Februari 2009 dan Hubungannya dengan Lama Hemodialisis. Jakarta: UI.

Sanabria, M, dkk. (2008). Dialysis outcomes in Colombia (DOC) study: A comparison of patient survival on peritoneal dialysis vs hemodialysis in Colombia. Kidney International. 73, S165-S172.

Seidel, UK, Gronewold, J, Volsek, M, Todica, O, Kribben, A, Bruck, H, dkk. (2014). Physical, Cognitive and Emosional Faktors Contributing to Quality of Life, Functional Health and Participation in Community Dwelling in Chronic Kidney Disease. PloS ONE. Vol. 9(3): e91176. doi: 10.1371/journal.pone.0091176.

Shao, M, Wang, S \& Parameswaran, PK. (2017). Hypoalbuminemia: a risk factor for acute kidney injury development and progression to chronic kidney disease in critically ill patients. Int Urol Nephrol. Vol. 
49(2):295-302. doi: 10.1007/s11255-016$1453-2$.

Steenkamp, R, Rao, A \& Fraser, S. (2005). UK Renal Registry 18th Annual Report (December 2015) Chapter 5: Survival and causes of death in UK adult patients on renal replacement therapy in 2014: National and centrespecific analyses. Nephron. 132(Suppl 1). hh: 111-144.

Sulistiawan, A, Marlenywati \& Ridha, A. (2014). Kualitas Hidup Pasien Gagal Ginjal Kronik di Ruang Hemodialisa Rumah Sakit Umum Soedarso Pontianak. Jurnal Mahasiswa dan Penelitian Kesehatan. Vol. 1(1). Hh: 10-21.

Tanno, K, dkk. (2013). Associations of marital status with mortality from all causes and mortality from cardiovascular disease in Japanese haemodialysis patients, Nephrology Dialysis Transplantation.Vol. 28(4). Hh: 1013-1020.

Utami, GT. (2015). Hubungan Dukungan Keluarga dengan Kualitas Hidup Pasien Gagal Ginjal Kronik yang Menjalani Terapi Hemodialisis di RSUD Arifin Achmad Pekanbaru. Jurnal Online Mahasiswa (JOM) Bidang Ilmu Keperawatan. Volume 2(1).

Valdivia, J, et al. (2013). Prognostic Factors in Hemodialysis Patients: Experience of a Havana Hospital. MEDICC Review, July 2013, Vol 15, No 3

Verberne, WR, dkk. (2016) Comparative
Survival among Older Adults with Advanced Kidney Disease Managed Conservatively Versus with Dialysis. Clin J Am Soc Nephrol.Vol. 11(4): 633640.

Wagner, M, Ansell, D, Kent, DM, dkk. (2011). Predicting Mortality in Incident Dialysis Patients: An Analysis of the United Kingdom Renal Registry. Am J Kidney Dis. 2011;57(6):894-902.

Wong, CF, McCarthy, M, Howse, MLP \& Williams, PS. (2007). Factors Affecting Survival in Advanced Chronic Kidney Disease Patients Who Choose Not to Receive Dialysis, Renal Failure. 29:6, 653-659, DOI: $10.1080 / 08860220701459634$.

Wong, B, dkk. (2018). Comparison of Patient Survival Between Hemodialysis and Peritoneal Dialysis Among Patients Eligible for Both Modalities. AJKD. Vol.71(3).

Xue JL, Everson SE, Constantini EG, dkk. (2002). Peritoneal and hemodialysis: II. Mortality risk associated with initial patient characteristics. Kidney Int.61:741-6.

Zahara, CFA. (2016). Perbandingan Lama Kelangsungan Hidup Antara Penderita Penyakit Ginjal Kronik yang Menjalani Hemodilisis dan Continuous Ambulatory Peritoneal Dialysis di RSUD dr. Zainoel Abidin Banda Aceh. Banda Aceh: FK US. 